\title{
Presbyterian Imitation Practices in Zachary Boyd's Nebuchadnezzars Fierie Furnace
}

\begin{abstract}
The university administrator, preacher and poet Zachary Boyd (1585-1653) relied heavily on epithets and similes borrowed from Josuah Sylvester's poetry when composing his scriptural versifications Zion's Flowers (c. 1640?). The composition of Boyd's adaptation of Daniel 3, Nebuchadnezzars Fierie Furnace, provides an unusually lucid example of the reading and imitation practices of a mid-seventeenth-century Scottish Presbyterian in the years preceding civil war. This article begins by re-considering a manuscript transcription of Fierie Furnace held at the British Library previously described as an anonymous playtext from the early 1610 s, then establishes the nature of Boyd's reliance on Sylvester by analyzing holograph manuscripts held at Glasgow University Library, a sermon Boyd wrote on the same theme, and the copy of Sylvester's Devine Weekes, and Workes that Boyd probably used.
\end{abstract}

\section{Keywords}

Zachary Boyd, Josuah Sylvester, Zion's Flowers, Harleian manuscripts, Book of Daniel, intertextuality 
Margarete Rösler edited Nebuchadnezzars Fierie Furnace: nach dem ms. Harl. 7578 for the series 'Materials for the Study of Old English Drama' in 1936. ${ }^{1}$ She transcribed the fourth item in British Library, Harleian MS 7578, a mid- to late-seventeenth century manuscript written in a fairly rapid but consistent secretary hand. The text is arranged on quarto sheets numbered consecutively from 321 to 368, with running heads and catchwords. Fierie Furnace is a verse adaptation of Daniel 3 that relates how Nebuchadnezzar set up a golden image and demanded that all should fall and worship it when summoned by music, or else be thrown into the eponymous furnace. Daniel's three companions Shadrach, Meshach and Abednego are threatened with burning when they refuse to pay homage. The manuscript breaks off at this point after 1459 lines, but the catchword 'Mens' on the final leaf indicates that the work did go on to relate the trio's miraculous escape from the fire. The text begins with a list of speakers, contains speech headings throughout, and has a single stage direction, 'The Kings Herauld conveeneth the princes etc.' (lines 76-7). Observing that the text is 'set out as nothing less than a drama' ('nichts weniger als dramatisch aufgebaut', viii), Rösler speculated that Fierie Furnace was a play performed in the 1600s or 1610s before James VI and I, whom she supposed was represented by Nebuchadnezzar. She believed its author to be the Jacobean translator and poet Josuah Sylvester based on the many close verbal similarities she discovered between Fierie Furnace and Sylvester's translations from Guillaume de Saluste Du Bartas'Semaines, published as Devine Weekes, and Workes (xii-xiv).

Susan Snyder disputed this attribution in her edition of Sylvester's translation, contending that 'Nebuchadnezzars Fierie Furnace appears to be the work not of Sylvester himself but of one of his fervent admirers, who borrowed his vocabulary and (rather mechanically) some of his phrases and conceits, but not other aspects of his style or his ideas'. ${ }^{2}$ Although Sylvester did indeed pursue royal patronage and wrote original divine poetry, Snyder correctly pointed out that the poem's style makes him an unlikely candidate for its authorship: the writer of Fierie Furnace wrenches the literal meaning of images in Devine Weekes to give them new figurative 
connotations; does not share Sylvester's 'taste for couplets shaped by antithesis, alliteration, and line-balance' (40); and in sum 'the pattern of these [borrowings] suggests not so much a writer to whom Sylvestrian phrasing comes naturally as one leafing through the Weekes as he writes' (41). Snyder also debunked the idea that Fierie Furnace was ever presented before James, remarking that the association between James and Nebuchadnezzar would be a 'strange kind of compliment' (41). Nonetheless, she maintained that Fierie Furnace was an 'unfinished play' (39). Her brief analysis left key questions about the manuscript unanswered: Who wrote it? When was it written? How much text is missing? Was it part of a collection of works? Why does the author imitate Sylvester so closely? If it is a play, when and where was it performed?

Nebuchadnezzars Fierie Furnace is in fact a dramatic poem written by the Scottish preacher and poet Zachary Boyd (1585-1653), who borrowed many epithets and similes from across Sylvester's oeuvre when writing his versifications from Scripture entitled Zion's Flowers. Establishing his authorship - easily done by consulting Boyd's holograph manuscripts in Glasgow University Library - does more than correct Rösler's and Snyder's earlier work: it encourages us to look closely at Boyd's use of Sylvester when composing his dramatic poems, adjust the probable date of composition to the 1630s, and so consider ways in which Boyd's distinctive imitation practices were appropriate for a Scottish Presbyterian denouncing idolatry and sycophantic bureaucracy in verse as civil war approached. This article begins by retracing the provenance of the Harleian MS 7578 text, and its relationship to Boyd's holograph manuscripts and the copy of Sylvester's Devine Weekes, and Workes (in the 1633 edition) which Boyd may well have used. After examining the implications of a date of composition for Zion's Flowers closer to 1640 and comparing Fierie Furnace with a sermon which Boyd preached on Daniel 3 at a similar time, the article then seeks to reconstruct how and why Boyd relied so heavily on specific passages from Sylvester as he re-applied multiple images and phrases in new contexts. 
Fierie Furnace does not read like a playtext suitable for early modern stage or closet performance. Fundamental to its structure are pleonastic repetitions replicated from Scripture, such as the sixitem list of instruments calling people to devotion (Daniel 3:5, 7, 10 and 15; cf. lines 448-9, 5201, 728-9, 760-1 and 924-5). The names of Nebuchadnezzar's various attendants - the princes, governors, captains, judges, treasurers, counsellors, sheriffs and rulers of the provinces (Daniel 3:2, 3 and 27) - are the nucleus of the work's entire structure: they are included in the list of 'speakers' at the work's beginning, and much of the text is taken up by sequences of bombastic speeches from each section of Nebuchadnezzar's entourage that advocate intolerance towards dissenters. The Harleian MS 7578 text contains six cycles of speeches (beginning at lines 93, 266, 464, 705, 990 and 1184), with numerous refrains voiced by the attendants that reiterate the same harsh stance towards non-observance, e.g.: 'If any will your image not adore/The fierie Furnace him shall soone devore' (lines 591-2, 610-11, 651-2 and 703-4). ${ }^{3}$ The debts to Sylvester make it almost impossible on chronological grounds that the work is related to the now-lost Elizabethan biblical drama Nebuchadnezzar (1596), which was performed eight times at the Rose theatre; moreover, Fierie Furnace does not contain features we would expect to find in a successful stage adaptation, such as Nebuchadnezzar vividly characterized as a proud warrior king. ${ }^{4}$ By contrast, Fierie Furnace's protagonist never wavers from the monotonous fustian of his opening lines (which contain phrases taken from Devine Weekes, II.i.4.713, I.i.64 and 176, and II.i.4.717-8):

Wee gods on earth should climb supernall stories

Wee should atchieve great things to grace our glories;

Behind us we should leave some cleare character

That wee have lived on this earths theater,

That afterdeath our names in all mens eyes

May be like starres that brandish in the skyes.

(lines 20-5) 
The other texts bound in Harleian MS 7578 offer no clues (these include a copy of Lydgate's Proverbs and verses by Humfrey Wanley) about the work's genre, and the remaining sections of this transcription (i.e. pages 1-320 and 369-end) have not been traced. Harleian MS 7518, however, has a clear genetic relationship with Harleian MS 7578 that has not been recorded previously. This second Harleian manuscript is a presentation copy of five poems from Zachary Boyd's Zion's Flowers: Pharaoh's Tyrannie and Death (fos 1r-42r), The History of Jephte (fos 42v-59v), History of Samson (fos 60r-100r), an incomplete David and Goliath (fos 100r-104v) and an incomplete Nebuchadnezzars Fierie Furnace (fos 105r-128v). Textual apparatus confirms the relationship to Harleian MS 7578: the running heads, catchwords, page numbers and list of speakers in both texts are identical, and both texts end abruptly on a page numbered 368 with the catchword 'Mens'. Given that the orthography in both texts is also very similar, it is highly likely that Harleian MS 7578 is a transcription of Harleian MS 7518 that follows the page lay-out of the fair copy. ${ }^{5}$ Moreover, Nebuchadnezzars Fierie Furnace in both the Harleian MS 7578 and 7518 texts corresponds closely to the holograph copy of Fierie Furnace held at Glasgow University Library. ${ }^{6}$ Since the holograph copy was removed to London until being repatriated in the mideighteenth century, Harleian MS 7518 may well have been copied directly from Boyd's original text, and Harleian MS 7578 from that transcription. ${ }^{7}$ Four other partial transcriptions of Boyd's poetry survive, one of which contains a full-length copy of Fierie Furnace as found in the holograph. ${ }^{8}$ The holograph manuscript alone is sufficient proof that Boyd wrote Nebucbadnezzars Fierie Furnace.

Fierie Furnace emerges as a poem containing almost 3000 lines in total, which makes it the longest of nineteen dramatic poems in the collection named Christian Poems for Spiritual Edification in Boyd's holograph, and subsequently better known as Zion's Flowers. This discovery provides new information about the genre, dating, and purpose of the text in Harleian MS 7578, and leads us to observe that Boyd drew extensively on Sylvester when writing his poetry. Indeed, once Sylvester's influence is acknowledged, we can observe direct borrowings across Boyd's poetic 
works: there are substantial debts to Sylvester in most of the other dramatic poems from his Zion's Flowers as well as in other works.

Boyd was a Church of Scotland minister closely associated with the University of Glasgow, and is celebrated today as a key figure in the institution's development (recognized today on the Memorial Gates outside the University's main building): he became vice-chancellor in 1644 , and bequeathed a substantial legacy to the college. He was a committed Calvinist and a moderate royalist initially reluctant to accept the Scottish Covenant, though he later did. ${ }^{9}$ Any resentment he expresses towards the English is reserved for pernicious Catholic and Arminian elements he perceived being harboured south of the border: Fierie Furnace reads as an attack on idolatrous behaviour condoned by the monarch and promoted by those around him. All Boyd's writing, including his poetry, is inspired by a kerygmatic vocation to demonstrate the strength and immediacy of spiritual concerns in politics and society. David W. Atkinson has argued that Boyd's literary aspirations have detracted from his posthumous reputation as a preacher, but his poetry and prose are perhaps better understood as different aspects of the same evangelizing mission. ${ }^{10}$ To an extent Boyd switches genres to propagate the same doctrinal truth for different settings and readers: he composed a long prose treatise, Last Battell of the Soule in Death (Edinburgh, 1628; ESTC 3446a.5) that seeks to provide succour and moral instruction on confronting death in the ars moriendi tradition, but also published a catechism for children designed for use each Sunday. ${ }^{11}$

His poetry was similarly written to proselytize. In Garden of Zion (1644), an entirely separate work from Zion's Flowers despite its similar title, Boyd commends the good counsel embedded in his scriptural adaptations to Charles I and appeals for God to 'teach me to compile / An usefull work; with grace now steel my stile/That whosoever reads this book he may/Reape profite, I comfort, thou praise for ay' (A7v; see also A2r-v). Boyd also composed English versions of the Old and New Testament songs, including a metrical psalter that was passed over 
by the General Assembly for use in church. ${ }^{12}$ Zion's Flowers is also didactic, as signalled by its epigraph taken from Psalms 119:54 (all references to the Authorized Version): 'Thy stactutes haue beene my songs / in the house of my pilgrimage.' A deleted beginning to Fierie Furnace similarly contains an epigraph, one which is directed at those in authority: '[Be wise O] yee kings; be instructed, yee Judges of the [Earth kiss] the son least he be angrie' (Psalms 2:10, 12). ${ }^{13}$ Zion's Flowers has been called 'Boyd's Bible', even though there are many books and chapters that he never versified, and several poems expand considerably on the Authorized Version, in contrast to the much closer versification of the Gospels in the manuscript poem Foure Evangels. ${ }^{14}$ The epithet 'Boyd's Bible' is fitting in so far as it encapsulates his poetry's devotional purpose, despite the term's derogatory undertone. Zion's Flowers has seldom been praised: the nineteenth-century critic John Cousin remarked on Boyd's 'uncouth verse', while John Lang found that Boyd 'was not a poet, yet he was something more than a mere doggerel rhymer [....] the commendable features are often marred not merely by rugged verse, but also by hard and unsympathetic thought'. ${ }^{15}$ Other writers could hear the textual instability created by Boyd's imitations from Sylvester without diagnosing the cause: Thomas Pennant complained about Boyd's incongruent phrases and images, and John Jamieson, who argued that Boyd's faults had been 'grossly exaggerated', is reported by a nineteenth-century writer to be among those believing 'that the ludicrous passages commonly printed as Boyd's are not really his'; he adds that Boyd 'did not entirely escape from the conceits and the affectation of quaint illustrations so prevalent in that age ${ }^{16}$ More recently, Atkinson made a partial defence of Boyd's verse when he wrote that it is not as uniformly wretched as it has been made out to be, nor is it without examples of artistically accomplished verse'. ${ }^{17}$ Both the merits and flaws of Boyd's poetry hinge on his use of Sylvester.

One reason the poems have not been read more widely, and the close connection with Sylvester's poetry not noticed, is that they largely survive only in manuscript. Despite a request in Boyd's Deed of Mortification that the college should publish his works, the four poems in Gabriel Neil's 1855 edition are the only sections of Zion's Flowers (discounting Rösler's Fierie 
Furnace) to have been printed. ${ }^{18}$ In that edition Neil observes similarities between Boyd's and Sylvester's styles: 'In general merit, our Author's Pieces and translations will stand a fair comparison with those of Sylvester [....] The similarity of Sylvester's works and talents to his own, had attracted the attention and won the esteem of our Author' (xiii). This comment is inspired by Boyd's one direct reference to Sylvester in print, when he quotes almost two hundred consecutive lines from 'The Vocation' (II.iii.1.667-862) in The Garden of Zion and explains that 'this paraphrase was made in verse by the Prince of English Poets, JOSHUA SYLVESTER'. ${ }^{19}$ Neil judiciously linked this phrase with the opening lines to Boyd's earlier verse celebration of the Covenanters' victory at Newburn, written in heroic couplets that are highly consonant with Sylvester's and owe specific debts to the beginning of Sylvester's First Week: 'O Prince of Poets, make my braine to boile, /With grace and verse, that I may now extoll / Gods praises high'. ${ }^{20}$ Neil did not apparently suspect that poetic fragments from Sylvester inhabited Boyd's works here or elsewhere. The only other earlier comment that may elicit any awareness of Boyd's alliance with Sylvester and Du Bartas is the following jibe from the seventeenth-century writer Samuel Colvil: 'Where one laughs at the Poems of Virgil, Homer, Ariosto, Du Bartas, etc twenty will laugh at those of John Cockburn, or Mr. Zacharie Boyd. ${ }^{21}$

Once the affiliation with Sylvester is accepted it quickly becomes apparent that Sylvester is a pervasive and constitutive influence on Boyd's verse. Of the nineteen poems in Zion's Flowers, all but one (The Historie of Jonah) contain specific linguistic affinities with Sylvester, as do most sections in another poem, the English Academie. Given how massive Boyd's and Sylvester's poetic corpuses are, it is not difficult to locate coincidental resonances between both works, but these are distinct from the substantial direct loans in Boyd's poetry being considered here. Though no references survive in print that unveil Boyd's practices, it seems likely that many of Boyd's contemporaries would have recognized loans from Sylvester. The first poem in Zion's Flowers, 'The Fall of Adam', can be read as a prelude that announces Boyd's intention to utilize Sylvester's works, first through lines with immediately recognizable similarities to the First Day 
(e.g. 'Immutable, immortall, mine alone, / and all sufficient, who have need of none/ Incomprehensible, omnipotent/Invisible, in working excellent'), and then through brief summaries of each day of creation with allusions to Sylvester's argument stanzas. ${ }^{22}$ In the poems that follow Boyd continues to consult Sylvester's work as he writes, borrowing many phrases and rhetorical figures from passages to expedite the rapid composition of his scriptural verse.

Sylvester was an obvious choice of model for writing divine poetry aimed at a broad readership. His translations from Du Bartas in particular were read widely in early modern England and Scotland: Devine Weekes, and Workes (London, 1605; ESTC 21649, with further editions in 1608, 1611 and 1613) was not just welcomed as a great translation of the French poet's Semaines, but was read and cited by a wide range of prose writers, including clergymen and scholars, for its factual information. ${ }^{23}$ As the work's title indicates, the poems were revered as popular divine (i.e. sacred and scripture-based) poetry: for example, William Scott, in his poetic treatise The Model of Poesy (c. 1599), found the Semaines comparable to the writings of the Italian Calvinist theologian Girolami Zanchi (a 'deepe diuyne and refiner of true Naturall knowledge’), which Du Bartas had 'minced and sugred for the weakest and tendrest stomak, yet throughly to satisfie the strongest judgements, ${ }^{24}$ Boyd also knew of Sylvester's other poems and translations, which were also primarily religious verse written in rhymed pentameter couplets. Sylvester entered Prince Henry's service once Devine Weekes was published, and after the prince's death, he dedicated two further volumes of poetry to Prince Charles, which contained further translations, original divine poetry and elegies for Henry; these are The Parliament of Vertues Royal (1614) and The Second Session of the Parliament of Vertues Reall (1615). A folio edition of Sylvester's complete works (Du Bartas his Dinine Weekes, and Workes with a Compleate Collectio [n] of all the other most Delightfull Workes) came out in 1621 (ESTC 21653), and was printed again in 1633 (ESTC 21654) and 1641 (Wing D2405). 
Boyd used one of these later folio editions. In addition to many citations from Devine Weekes, Zion's Flowers contains material from several other poems that were printed together for the first time in 1621. In Fierie Furnace, for example, Boyd refers to several page openings in the folio texts of Job Triumphant and Quadrains of Pibrac. ${ }^{25}$ He used numerous other poems from that folio edition too, such as Maiden's Blush: or Joseph, which supplies Boyd's Joseph Tempted to Adultery with factual details; Memorials of Mortalitie, used in the thirteenth and fourteenth days' exercises in English Academie; and even a dedicatory verse to Robert Nicholson before The Profit of Imprisonment. ${ }^{26}$ Because he seldom refers to the same passage twice, we might expect that Boyd marked his copy to show which lines he had used. ${ }^{27}$ A copy of the 1633 folio inscribed with Glasgow College's name (Glasgow University Library, shelfmark Sp Coll Bm3-c.6) has annotations that seem to have served just this purpose: it contains an extensive series of careful markings, roughly one every four lines on average, alongside the margins on both columns of each page against individual lines. There are marks throughout Devine Weekes and in all the works just mentioned, as well as in other poems including paratextual verses like the dedicatory corona (A2r-v), John Vicars's epitaph to Sylvester (A6r) and even 'The Printer to the Reader' (B1r). ${ }^{28}$ In the same ink are written three verbal annotations in a seventeenth-century hand resembling Boyd's, though the sample is too small to accept or deny that attribution with any confidence. ${ }^{29}$ In addition, there are similes marked with crosses and double-crosses throughout the book, particularly in the translations from the Semaines. The majority of lines that Boyd imitates are marked in this copy, while the frequency of single lines, incomplete grammatical units, and lines unremarkable except for the single phrase that Boyd uses all indicate that he probably marked lines that he imitated in this copy; for example, a double mark against one line (F2r, line beginning 'In vain') may correspond to Boyd quoting twice from that line in succession in Fierie Furnace (lines 361-3). The Glasgow copy can be provisionally treated as important evidence for reconstructing the author's processes of imitation. 
Boyd's certain use of a 1621 or later edition, probably the 1633 printing, revises the likely date of composition of Zion's Flowers. Boyd's manuscript offers few clues otherwise: there are no dates, and the presence of Popish Powder Plot (based on the 1605 Gunpowder Plot) and World's Vanities (appended in prose to Boyd's Last Battell in 1629) is not reliable evidence for composition of the rest of the manuscript. ${ }^{30}$ Gabriel Neil supposed that the poems were composed when Boyd was in France between 1607 and 1623 because they contain allusions specific to French culture. Although Neil does not cite specific examples, such allusions may well have another source: Du Bartas' and other French poets' verse as quoted by Boyd from the Sylvester folio. There are other reasons to suppose that the date of composition was definitely after 1621 , and probably closer to 1640 . A post- 1633 date is attractive because, in addition to the printing of the second edition of Sylvester's folio, the Authorized Version was published in Edinburgh for the first time to mark Charles' formal coronation in Scotland. Boyd's sermons on 'Nebuchadnezzar's Fierie Furnace' which survive in manuscript reveal an interpretation of the Authorized Version text of Daniel sensitive to the theological and political context of the preCivil War years, which is carried through into Fierie Furnace as well: these eight sermons are undated but are bound in a miscellaneous collection of sermons that includes two that were preached in $1643 .^{31}$ The Battel of Newburne and Garden of Zion show that Sylvester's poetry and Charles' policies were both in Boyd's mind in the early 1640s, as was the idea of a verse bible. Both the sermons and dramatic poems may be responses to the same political conditions in the period 1638-43. Regardless of the poem's exact date of composition, Fierie Furnace is analogous in important ways to the 'Fierie Furnace' sermons, and it is worth developing this exegetical context for Boyd's poetic compositions which will help us to reconstruct his processes of appropriating material from Devine Weekes. 
Atkinson finds that Boyd's methods of scriptural interpretation closely follow the scheme described in the puritan preacher William Perkins' Arte of Prophesying (published in Latin, 1592; in English, 1607). ${ }^{32}$ Perkins writes that preparation of a text involves interpretation and 'division or

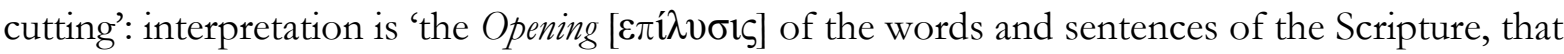
one entire and naturall sense may appear' $(\mathrm{C} 4 \mathrm{v})$, and 'division or cutting' meant 'resolution' of a text into an edifying form, either through direct 'notation' of the biblical verse if it expressed doctrine, or else through 'collection' to extract meaning through one of nine arguments ('causes, effects, subiects, adiuncts, dissentenies, names, distribution, and definition', G3v). The eight 'Fierie Furnace' sermons are a verse-by-verse exposition of Daniel 3 that interpret, divide and resolve each line of Scripture and foreground the 'Use' of each section in ways comparable to structures in Fierie Furnace. Writing in a plain style, Boyd explicates narrative and textual details from Daniel in both works.

The first sermon, which interprets the first seven verses, establishes a process used in other sermons and has strong thematic analogies to Fierie Furnace. Boyd first supplies the Authorized Version text (4r-v), and then explains the 'division of the chapter' as a whole into six parts, and the 'division of the text' into four parts which Boyd treats in turn. The six parts of the chapter's division correspond to the episodic structure of Fierie Furnace, reinforced by the attendants' cycles of speeches, e.g.: the speakers obsessively repeat the central idea of the first part, 'how Nebuchadnezzar did dedicate an exceeding great image of gold in the field of Dura for to be worshipped by all his subiects', and of the second, 'Shadrach Meshach and Abednego are accused for not worshipping that image' (4r). In four sections that discuss aspects of the scriptural text, Boyd pays close heed to specific phrasing and figures: for example, he 'collects' the significance of Dura (mentioned in Daniel 3:1) by turning to Ptolomy's Geography. The same attention to detail appears in Fierie Furnace: 'Dura' recurs in the locutions 'Duras field' rhymed with 'yeeld' (lines 701-2, 730-1, 762-3 and 786-7), or 'Duras plaine' rhymed with 'ordaine' or 
disdaine' (lines 50-1, 80-1, 115-6, 441-2 (647-8, 'remaine'), 895-6 and 909-10). Perkins writes about biblical rhetoric, concluding that: 'All tropes are emphaticall, and besides delight and ornament they doe also afford matter for the nourishment of faith' (E8v). Boyd is especially sensitive to emphatic pleonasm: for example, he informs the reader of his sermon (the work is introduced with a preface 'To the Reader') that 'the image is called his not once, as if the preacher were afraide to speake it, but four times it is called the image which Nebuchadnezzar the king has set up' (7r), and repeatedly uses the same verb 'set up' (found in the Authorized Version) in his poem.

The sermons elucidate the reasons behind Boyd's dedicated repetition of the names of the King's attendants in the poems: Boyd is cautioning both monarchs and the wider populace that 'great men if they be not good men are the fittest men to bring in idolatrie' (10r). He advocates suspicion concerning 'outward appearance in matters of religion', declaring that 'wee must not say, the King the Princes, the treasurers and sheriffs are of such a religion, and therefore I will follow them, I will be ruled by authoritie' (11r). He reinforces his point using the same pleonasm later in the sermon: 'learne heere not to trust in men of whatsoever degree whether princes governours captaines treasurers counsellors or people, trust only in God' (17r). The omission of the king from this list is surely deliberate: Boyd's agenda is not republican, but Presbyterian. His 'To the Reader' outlines an intention only to admonish: 'Kings and princes and all that are in authoritie may leerne what not to command, and also where subjects may learne in what not to obeye' (2r). If Nebuchadnezzar is keyed to any historical figure, it is the Pope: 'Let all men judge if Papists have reason thus to rage to banish, burne, herd and hang Gods ['Dan 3.' in margin] shadrachs who are willing to yield there bodies that they may not serve nor worship any God except their owne god, to whom be glory for ever' (3r). These sentiments are brought to the surface in the Battel of Newburne, which celebrates the Scottish victory over Arminians, Catholics, and episcopalian 'Canturburians' (but not the king). This current of ideas confirms the real polemical drift behind the extraordinary structure of Fierie Furnace, which has no equivalent 
elsewhere in Zion's Flowers: the cycles of speeches are a denunciation of unscrupulous officials who lead the king astray. The 'Use' at the conclusion of Fierie Furnace asserts the limited moral jurisdiction held by those in office: 'Let all heere learn, who would have rest or ease/To study still the living Lord to please / More then all Men that are of high Degree/Though Kings be high, the Lord is the most Hie/Of Shadrac, Meshach and Abednego. ${ }^{33}$

Just as Boyd's attention to scriptural detail in Fierie Furnace matches his confessional stance, so do his methods of imitation. Sylvester, like Du Bartas, wrote poetry closely associated with the Stuart establishment: Devine Weekes, and Workes contains extravagant dedicatory materials to James VI and I (known as an admirer of Du Bartas) in all editions. Nowhere in Zion's Flowers does Boyd take direction or inspiration from Du Bartas' or any other poet's words for the content, narrative or moral message of his dramatic poems, even in The Towre of Babylon, which draws on Sylvester's 'Babylon' alongside Genesis 11, and David and Goliath, which is influenced by Sylvester's account in 'Trophies' (II.i.4) as well as 1 Samuel. Though Sylvester's poetry does not impinge on Fierie Furnace's biblical inspiration or structuration, it does make the poem's rhetoric, superficially at least, more compelling. Boyd relies on Sylvester solely to raise the rhetorical pitch of his divine poetry, almost as a practical aid at times. He consistently borrows the vehicle, but never the tenor, of Sylvester's metaphors. The 'Use' passage from Fierie Furnace offers a good example: embedded in Boyd's didactic verse is an extended simile that compares God's agency to a stone that creates ripples when thrown into a pond. The simile and much of the phrasing, but not the application, is taken from Sylvester's 'The Colonies':

Ev'n as a stone \that/ amis'd a pond ye fling

About his fall first forms a little ring

Wherein new Circles, one in other growing

(Through the smooth waters ever gently flowing)

Still one the others more and more compell 
From the ponds centre, where the stone first fell

Till at the last the largest of the rounds

From side to side 'gainst ev'ry bank or bounds;

So at the first God unto wrath is slow

His plagues are little but they overflow

The Bank, at last, not bounded with a border

Their widest circle brings all in disorder.

(Boyd, Additional MS 34781, fol. 116r)

For, as a stone that midst a Pond yee fling,

About his fall first formes a little ring,

Wherein, new Circles one in other growing

(Through the smooth Waters gentle-gentle flowing)

Still one the other more and more compell

From the Ponds Center, where the stone first fell;

Till at the last the largest of the Rounds

From side to side gainst every banke rebounds:

So, from th'Earths Center (where I heere suppose

About the Place where God did Tongues transpose)

Man (day by day his wit repolishing)

Makes all the Arts through all the Earth to spring

(Sylvester, II.ii.3.297-308)

Boyd's reduplication here is untypical in quoting almost verbatim from Sylvester, for Boyd much more often stops short of quoting entire lines, sometimes changing a single noun or word-form only, e.g.: 'The lime it crumbles from the yawning chinks' (line 318, cf. 'The mortar crumbles from the yawning chinks', II.iii.4.208); 'My feet are feathr'd with the wings of Hope' (line 979, cf. 'Their feet are feathered with the wings of Hope', II.iii.4.344). ${ }^{34}$ On the other hand, this example is absolutely characteristic of Boyd's practice in that he manipulates a piece of rhetorical 
decoration and applies it to a totally different referent: in Sylvester, the simile describes humankind's dispersal across the earth; in Boyd, it describes the unfolding of God's providential wrath. Another characteristic feature of Boyd's imitations is that multiple quotations from a section of Devine Weekes appear together, which provides corroboration that Boyd consciously borrowed material from specific sections of the poems. In this case, just over ten lines before using this simile, Boyd has taken several phrases from a couplet found almost twenty lines earlier in Sylvester, at the bottom of the previous leaf ('th'Earths thick Shade/Eclipst the silver browes of Cynthia bright, / And her browne shadow quencht her brothers light, II.ii.3.278-80; N5r): 'The moon we see with silver brows most bright/Ecclipst anone and als her brothers light/With dark browne shawdow colour'd like a sack' (Additional MS 34781, fol. 116r). Such insertions serve as poetic ornaments which surround more forthright proclamations that Boyd composes without assistance, e.g.:

It's not fir Kings, to make their will a Law

To great and small; but they should stand in aw

And not ordaine; but what God doth command

Who only Lord is both of sea and land.

Boyd's recourse to specific openings in Sylvester's folio to supplement the rhetorical interest of his didactic poetry is evident throughout Fierie Furnace. Again, the author seems to select passages solely for poetic style, oblivious to content. The poem contains a high frequency of borrowings, even when compared to other poems in Zion's Flowers: in the text edited by Rösler, almost one in every five lines has a direct verbal parallel with Devine Weekes. ${ }^{35}$ There are further references throughout the second half. ${ }^{36}$ Boyd's habit of taking two or more quotations from the same section at once allows us to trace Boyd's eye roving across pages: for example, within fifty lines Boyd takes at least six phrases from three leaves at the conclusion to 'The Captaines' (II.iii.4, S3v-5r): 'thunder throwing hand' and 'command' (lines 888-9; cf. II.iii.4.909- 
10, S3v); 'belch or bark' with 'dark' (lines 913-14; cf. II.iii.4.1203-4, S5r); 'They not reforme, but should deforme my state’ with 'debate' (lines 917-18; cf. II.iii.4.1211-12, S5r); 'sacred Helme exclude' (line 920; cf. II.iii.4.1085, S4v); 'in gentle sort' (line 939; cf. II.iii.4.1216, S5r); and 'leach' (line 941; cf. II.iii.4.1215, S5r). Such borrowings are insensitive to context, and at times perfunctory: Boyd loans rhyming pairs from Sylvester on about sixty occasions (i.e. most couplets listed in Rösler and in note 37). He continually resorts to Sylvester's works to provide local colour and vivid examples without detracting from his biblical exegesis. Such tissues of quotations barely amount to stylistic imitation of Sylvester, especially when Boyd's original couplets fall so far short of emulating Sylvester's. Boyd does not conceal appropriations either: early readers could well have recognized the provenance of such phrases containing distinctive alliteration and reduplication as 'perill proof' (line 451; II.iii.2.63-4), 'too too malapert' (line 771; II.iv.3.83) and 'porke porking cry' (line 1002; II.iv.3.274). Loans from Sylvester are sporadically underlined throughout Zion's Flowers and English Academie, though passages are not underlined consistently enough to suggest that this was a deliberate strategy. On other occasions, Boyd appears to recollect individual phrases and lines from memory: the distinctive phrase 'dizzie darnell seed' (II.iv.4.411-12) appears in Fierie Furnace (line 1097) as well as in Joseph Sold by his Brethren (Gen MS 393, 211r) and Fall of Adam (17v). When one of the best-known passages in Devine Weekes is used in the second half of Fierie Furnace (marked in the Glasgow folio), Boyd may not have needed to consult the printed text: 'Of them I shall a Booke in Folio make/That by them others may Example take' (Additional MS 34781, 113v). There are occasional moments of original imitation as well, though. In several places Boyd includes related catalogues of trees, animals and other natural phenomena that are compiled by Boyd, but are nonetheless highly reminiscent of Devine Weekes, e.g.:

The wel wood pecker and the draick and ducke

The Kestrell, rough the rear, raven, Gull, the Jay

The Jackdaw and the Griffon strange for pray 
The Pelican, the phenix, and the brush

The facone ferice which down with force doth rush. ${ }^{37}$

These observations about Boyd's borrowings from Sylvester's poetry illustrate ways in which Boyd's imitation practices were idiosyncratic but broadly consistent with Presbyterian attitudes to Scripture and the purpose of poetry. The Authorized Version provided Boyd with his primary narrative source and key repeated details which are also analyzed in his sermons. Boyd clearly viewed Devine Weekes, and Workes as a great precedent for writing vernacular divine poetry, but his verse only conforms outwardly to Sylvester's rhetoric, remaining virtually unmoved by its content. Devine Weekes serves as a metonym for a monarchical legal authority that for Boyd no longer implied spiritual or moral sovereignity in either the king's person or literary works closely associated with him. The strength of Du Bartas' earlier reputation in Jacobean Scotland, centred on James VI's admiration, may linger in Boyd's verse, but Zion's Flowers primarily shows that Sylvester's poetry had become a ready precedent for writing religious verse. Quotations from Sylvester's interpolations (which other writers often avoid) and prefatory poems in Devine Weekes illustrate that Boyd's attention was not focused on interpreting Du Bartas' poetry; quotations from Francis Quarles's Divine Poems show Boyd picking rhetorical flowers from the works of another popular Calvinist poet too. ${ }^{38}$ Boyd appears to have been writing popular redactions of biblical narratives which were intended to reach the same readers who might have enjoyed Sylvester's and Quarles's poetry. Boyd was not attempting to supersede Sylvester, but to adapt aspects of his poetry as a vehicle for composing works directed at a similar readership. Boyd's Fierie Furnace is a pragmatic attempt to distill scriptural narrative and didactic comment into more accessible, entertaining forms, to which end Boyd's imitations from Sylvester are a subsidiary aid.

A complete electronic or printed text of Boyd's poetry would undoubtedly yield further insights into Boyd's methods of reading and imitation and their links with his wider literary and 
ecclesiastical career. Such an edition might cross-check the entire Zion's Flowers systematically against Sylvester's works, the Authorized Version and Quarles' poems, and discern the exact connection to the annotated Glasgow folio. Boyd's use of his source texts for each of the nineteen poems in Zion's Flowers could be compared in order to witness how widely his practice diverged between sections, and how far this corresponds to the demands of the particular section he was writing; Boyd's other poems, especially English Academie and Battel of Newburne, require similar close analysis to investigate what role Sylvester's works played in their composition. Boyd's reading practice across all his poems needs to be consolidated into a single comparative analysis of how he navigated Devine Weekes, and Workes to pick out epithets and similes, which would reveal the strategies and habits he developed while writing. This article has shown how Boyd's habits of reading and imitation reflect the literary, political and theological assumptions of a Scottish Presbyterian in the years preceding civil war. Further work would develop our understanding of how seventeenth-century imitation practices were affected by Protestant and political allegiances, intended readership or audience and even (if Boyd's contemporaries did recognize his appropriations as mere appropriations) the material survival of a heavily imitative text like Zion's Flowers in manuscript only. Council. 


\section{Notes}

1. All quotations from the section of Fierie Furnace edited by Rösler (i.e. the first 1459 lines) are taken from this edition; page and line numbers will follow in brackets. When quoting from unprinted later sections, folio numbers from manuscript sources are given.

2. Snyder, Divine Weeks and Works, I, 41. All subsequent quotations from Devine Weekes are taken from this edition. Page numbers (from volume one), and line numbers will follow in brackets. 3. Other refrains appear at lines 193-6, 220-3, 233-6 and 262-5; 510-11, 529-30 and 564-5; 10489, 1066-7, 1085-6, 1106-7 and 1127-8; 1252 and 1301; and 1361-2 and 1378-9.

4. Connolly, 'Peele's David and Bethsabe,' 17.

5. e.g. spellings such as 'atchieve' (line 21) and 'powr/ towr' (lines 105-06) appear in both. Rösler's emendations of transcription errors (e.g. lines 637 and 1323, which are found in the Harleian MS 7518 text as well) match Boyd's holograph copy, though in line 384 the deleted 'fry', replaced by 'try' (also found in Harleian MS 7518), is authorial. It is not obvious whether minor discrepancies and scribal errors (e.g. 'wretched eøle clod', Harleian MS 7578, 34v) were introduced when transcribing from one to the other, or transcribing from the original holograph. 6. Gen MS 394, fos 139r-180v. All Gen MS manuscripts referred to are held by Glasgow University Library, and I thank the librarians there for their assistance.

7. University records report that in January 1760 the manuscripts 'belong[ed] to the public library, but had been taken out of it and lost before the Revolution, [and] were now in the possession of Mr Bernard Baine Apothecary in London' (Glasgow University Library, Clerk's Press MS, 30).

8. British Library, Additional MS 34781 contains later seventeenth-century transcriptions in a cursive, mixed hand of the same poems found in Harleian MS 7518 without omissions. A late seventeenth- or early eighteenth-century transcription of the same sections once in Bristol, but now held at Glasgow University Library (Gen MS 151) may have originated from the same 
source. A mid- to late-seventeenth century transcription in British Library, Additional MS 10310 (entitled 'Christian Poems for spirituall ædificatione') contains ten poems from Zion's Flowers not found in Harleian MS 7518. An eighteenth-century transcription of eight poems from the holograph now held by the Mitchell Library (numbered series, MS 33) contains lengthy descriptions of its previous owners: it is attributed to the Scottish physician William Hunter, who presented it to John Pringle (president of the Royal Society in 1772); it later came into a Mr Nasmyth's possession in the mid-1870s, who restored the text using Harleian MS 7518.

9. Atkinson, 'Boyd, Zachary (1585-1653)'.

10. Atkinson, Sermons of Zachary Boyd, xv-xvi.

11. Cleare Forme of Catechising; Atkinson, 'Zachary Boyd and the Ars Moriendi Tradition'. 12. Songs of the Old and New Testament, Atkinson, 'Boyd'.

13. Gen MS 394, fol. 208v.

14. Neil, Four Poems, 7. The Foure Evangels, Gen MS 400.

15. Cousin, Short Bibliographical Dictionary, 44; Lang, Glasgow and the Barony thereof, 48-9.

16. Slezer, Theatrum Scotiae; Pennant, 'Second Tour', 240. 'Appendix', 359.

17. Atkinson, 'Zachary Boyd: A Reassessment', 438.

18. Neil, Four Poems, 22-3.

19. Boyd, Garden of Zion, B7r-C4v (B7r).

20. Battel of Newburne, 4. Sample imitations: 'With hideous roaring and with sulphy flash [...] The hills about did greatly grone and grumble’ (5; cf. I.ii.701-4); 'Terrours from heaven made all the footmen flee/By an backside with blushing infamie' (7; cf. I.ii.716); 'Poyson'd the air with their blasphemous Braves' (9; I.i.779).

21. Colvil, Mock Poem, A7r. Cockburn was a late seventeenth-century Scottish minister, but his ODNB entry does not mention any poetic works (Clarke, 'Cockburn, John (1652-1729)'). 
22. Additional MS 10310, 2v (cf. I.i.45-8), and 3r: 'The fifth day shall the fishes of the sea/mind to make with foules in air to flee./In the sixth day have it in my mind/The creeping things and Cattell of each kinde' (cf. Arguments to Fifth and Sixth Days in Snyder, I, 231 and 262).

23. Auger, 'Semaines' Dissemination'.

24. British Library, Additional MS 81083, 11r. An edition of The Model is due to be published by Cambridge University Press.

25. For parallels with Job Triumphant (references to Literature Online text) see: Fierie Furnace lines 137-8 (JT 801-2), 139-42 (685-8); 144 (733); 145 (739-40); 148 (668); 156 (622); 225 (911-12); 228 (866); 229 (863). For Quadrains of Pibrac (also Literature Online text) see: Fierie Furnace lines 1402 (QP 425); 1404 (423); 1405 (360); 1410 (50); 1415 (81); 1416 (83).

26. For Joseph Tempted see, for example, Neil (ed.), 51 (MB 580) and 93 (MB 999). The poem also contains details from Triumph of Faith, 91 (canto 3, st. 33 and canto 2, st. 29). For English Academie see Gen MS 401, 165r, 13.29 ('Like vnto trees wee bloome and bud/wee ripen, at last wee rot, / And after that lye downe in mud,/ thus to the grave we trot' (cf. MM st. 11, 2Y6r (Devine Weekes (1633)) and 183r, 14.44 ('Trust not in great prosperity, / For all such earthly things / Are ushers of adversity / and take them to there wings' (cf. MM st. 89, Z4v)). For the Nicholson poem (2D3r), cf., Jacob and Esau Reconciled, Gen MS 393, 184r: 'Links of my kindnesse I doe never breake,/ Those that me serve I never will forsake: /Where I doe love, sincere is my affection, / All such I will take under my protection/ As brookes that downe high horned cliffs doe rush'.

27. In Fierie Furnace, for example, II.iv.4.1028 is used at line 1456, and 1032 in the next line, 1030 has been used four hundred lines earlier, at line 1071, and 1055-6 was used at lines 1003-4. 28. All signature numbers from Devine Weekes and Workes are from the 1633 folio edition (ESTC 21654).

29. 'a gun' on G6r, 'servile'[?] on $2 \mathrm{I} 2 \mathrm{v}$ and 'arbiter' on $2 \mathrm{R} 5 \mathrm{v}$. 
30. Cf. Neil, Four Poems, 10. For evidence that Boyd transcribed Zion's Flowers from an earlier copy, see Gen MS 394, fol. 143r, where 'At all your wordes which godly are indeede' appears, struck out after the line ending 'browe' and before the one ending 'see', but inserted after 'heade' and before the line concluding 'allowe' in order to rhyme.

31. 'Fierie Furnace of King Nebucha \d/nezzar'. Item 12 was preached on 26 February 1643, and item 13 in March 1643. When quoting from these sermons, folio numbers will follow in brackets.

32. Atkinson, Sermons, xxxi.

33. Additional MS 34781, 116r.

34. Two other exceptions, also from 'The Colonies', are found in Dinah Ravished by Shechem: one is the same stone-in-water analogy just quoted (Neil, Four Poems, 149; cf. II.ii.3.297-304), and the other also draws on natural imagery: 'birds which downie feather'd, young, / Still feare to flie before their quils be strong' (150: cf. II.ii.3.31-2).

35. Approximately 270 lines out of 1460. Parallels not noted by Rösler (excluding those already mentioned above) are in lines 9-11 (II.i.iv.701-02); 29 (II.i.iv.556); 32-3 (II.ii.1.231-2); 90 (I.iv.785); 338-9 (II.iii.1.777-8); 361 (I.v.25); 451 (II.iii.2.64); 455 (II.iii.2.284); 472 (I.vii.28); 540-1 (II.i.2.28990); 556-7 (II.i.2.541-2); 562-3 (II.i.3.449-50); 631-2 (II.ii.3.847-8); 641-2 (II.iii.3.85-6); 644 (II.iii.3.962); 654-5 (II.iii.3.1481-2); 669 (II.iii.4.264); 670-1 (II.iii.4.765-6); 676-7 (II.iii.4.665-6); 683-4 (II.iv.1.691-2); 693-4 (II.iv.1.901-2); 697-8 (I.v.871-82); 719 (II.iv.2.327); 750-1 (II.iv.2.6878); 814-5 (II.i.2.289-90); 824-5 (II.i.3.93-4); 826-7 (II.i.3.329); 873 (II.iv.1.585); 888-9 (II.iii.4.90910); 917-18 (II.iii.4.1211-12); 920 (II.iii.4.1085); 939 (II.iii.4.1216); 970 (II.iii.1.789); 1003-4 (II.iv.4.1055-6); 1071 (II.iv.4.1080); 1080-1 (II.iv.4.585-6); 1109-10 (II.iv.3.907); 1160-1 (II.iv.2.262); 1168 (II.iv.2.1143); 1191 (II.iv.2.208); 1213-14 (II.iv.1.1049-50); 1223 (I.vii.285); 122930 (I.vii.265-6); 1231-2 (I.vii.143-4); 1233 (I.vii.221); 1280-1 (II.i.3.154-6); 1291-2 (II.i.3.149-50); and 1333-4 (II.iv.1.117-18). 
36. e.g. 'Let there owne sputtle on their face be driv'n/Such in a fierie furnace cast anowe/That all may learne to stoup before your throne' (Additional MS 34781, 107v; cf. II.iv.iii.606); 'and all our confidence / Like naughty spiders brittle residence', 109v; cf. JT 548); 'Soon let the furnace with its whiffing fire / Burn up these rebells flesh and bones intire' (112r; II.iv.3.609-10). 37. Fall of Adam, Additional MS 10310, 7v; cf. Flood of Noah, 94r-v; and for English Academie see Neil, Biographical Sketch, xxxviii-ix.

38. For an interpolation quoted by Boyd, see e.g. Abraham Commanded to Sacrifice Isaac, 'Hee doth not lye on pillowes of securitie / Or beastlie snorts on downe beds of impuritie; / As those whose senses overgrowne with fat, / No doore have left for grace to enter at' (I.ii.917-20). For Quarles quotations, see, for example, Historie of Samson and Historie of Jeptha which borrow from the Historie of Queene Ester, and the nineteenth to twenty-first days' exercises in The English Academie (Gen MS 400, 247r-273r) which borrow from the introduction and author's apology to $A$ Feast for Worms and Ester.

\section{Bibliography}

'Appendix: Some Account of the Life and Writings of Zachary Boyd.' In John MacUre, The History of Glasgow (1736), 355-63. Glasgow: Hutchinson and Brookman, 1830.

Atkinson, David W., 'Boyd, Zachary (1585-1653).' In Oxford Dictionary of National Biography (2009). doi: 10.1093/ref:odnb/3119.

Atkinson, David W., ed. Selected Sermons of Zachary Boyd. Glasgow: Aberdeen University Press, 1989.

Atkinson, David W. 'Zachary Boyd and the Ars Moriendi Tradition.' Scottish Literary Journal, 4.1 (1977): 5-16. 
Atkinson, David W. 'Zachary Boyd: A Reassessment.' In Proceedings of the Third International Conference on Scottish Language and Literature, edited by Roderick J. Lyall and Felicity Riddy, 438-56. Stirling: University of Glasgow, 1981.

Auger, Peter. 'The Semaines' Dissemination in England and Scotland until 1641.' Renaissance Studies, 65 (2012): 625-40.

Boyd, Zachary. Battel of Newburne. Glasgow, 1643; Wing B142.

Boyd, Zachary. Cleare Forme of Catechising, before the giving of the Sacrament of the Lord's Supper. Glasgow, 1639; ESTC 3446.

Boyd, Zachary. 'The Fierie Furnace of King Nebucha \d/nezzar/preached in eight sermons.' Glasgow University Library, Gen MS 386, item 1.

Boyd, Zachary. Four Poems from 'Zion's Flowers'. edited by Gabriel Neil. Glasgow, 1855.

Boyd, Zachary. The Foure Evangels. Glasgow University Library, Gen MS 400.

Boyd, Zachary. Nebuchadnezzars Fierie Furnace [extract]. British Library, Harleian MS 7578, item 4.

Boyd, Zachary. The Songs of the Old and New Testament in Meeter. Glasgow, 1648; Wing B3910.

Clarke, Tristram. 'Cockburn, John (1652-1729).' In Oxford Dictionary of National Biography (2009). doi:10.1093/ref:odnb/5774.

Colvil, Samuel, Mock Poem, or, Whiggs Supplication. London, 1681; Wing C5426.

Connolly, Annaliese. 'Peele's David and Bethsabe: Reconsidering Biblical Drama of the Long 1590s.' Early Modern Literary Studies, Special Issue 16(2007): 9.1-20.

Cousin, John W. A Short Bibliographical Dictionary of English Literature. London: J. M. Dent \& Sons, 1910.

Lang, John Marshall. Glasgow and the Barony thereof. Glasgow: James MacLehose and sons, 1895.

Neil, Gabriel. Biographical Sketch of the Rev. Zachary Boyd. Glasgow: G. Richardson, 1832. 
Pennant, Thomas. 'Pennant's Second Tour in Scotland.' In A General Collection of the Best and Most Interesting Voyages and Travels in all Parts of the World, edited by John Pinkerton, 171-569. London, 1809.

Rösler, Margarete, ed. Nebuchadnezzars Fierie Furnace. Louvain: Ch. Uystpruyst, 1936.

Slezer, John. Theatrum Scotiae, ed. by John Jamieson. Edinburgh: William Paterson and Henry Sotheran, 1874.

Snyder, Susan, ed. The Divine Weeks and Works of Guillaume de Saluste, Sieur du Bartas, translated by Josuah Sylvester. 2 vols. Oxford: Clarendon Press, 1979. 